УДК 619:616.98:578

doi: $10.36359 /$ scivp.2019-20-2.22

\title{
ЕФЕКТИВНІ ІННОВАЦІЇ 3 ПРОФІЛАКТИКИ НЬЮКАСЛСЬКОЇ ХВОРОБИ ПТИЦІ
}

\author{
I. К. Авдос'єва, канд. вет. наук, \\ О. Б. Басараб, старший науковий співробітник, \\ B. В. Регенчук, завідувач сектору, \\ I. Л. Мельничук, старший науковий співробітник
}

Державний науково-дослідний контрольний інститут ветеринарних препаратів та кормових добавок, вул. Донецька, 11, м. Львів, 79019, Україна

У статті представлені дані порівняльної очінки 2-х методів серологічного контролю ефективності вакцинації бройлерів вакциною ВЕКТОРМУН HVT-NDV проти ньюкаслської хвороби (НХ). Встановлено, щуо обидва методи як IФА (тест-система фірми ID vet, Франція), так РЗГА є чутливі і виявляють протективні антитіла до вірусу НХ у сироватках крові бройлерів. Одноразова вакииначія у інкубаторі векторною вакциною ВЕКТОРМУН HVT-NDV проти НХ є абсолютно достатньою для формування та створення стійкого імунітету проти НХ, дозволяе знизити вплив стресу у порівнянні з масовими вакцинаціями в пташнику методом випоювання.

При застосуванні векторної вакиини відсутне горизонтальне поширення вакцинного вірусу: виключається ризик зараження навколишнього середовища збудниками вірусних хвороб, яке може призвести до безконтрольного зараження птиці.

Застосування векторної вакцини забезпечує стабільну епізоотичну ситуацію в господарстві: не викликає побічних реакиій, потирення вакцинного вірусу («ролінг» інфекція), підвищуе імунний статус стада, тим самим знижує негативний вплив вірусних та бактеріальних агентів на організм птиџі протягом періоду вирощування та кількість вакцинацій птиці, викликає тривалий імунітет, тому, як правило, відсутня необхідність ревакцинації в польових умовах.

Ключові слова: НЬЮКАСЛСЬКА ХВОРОБА, ВЕКТОРНІ ВАКЦИНИ, ВЕКТОРМУН HVT-NDV, РЕАКЦІЯ ЗАТРИМКИ ГЕМАГЛЮТНАЦІЇ, ІФА, ТЕСТ-НАБІР.

Існуючі вакцини проти ньюкаслської хвороби (НХ) зменшують, але не усувають польову інфекцію в стаді, при цьому зберігається можливість поширення інфекції та підвищення вірулентності вірусу. Важливими питаннями при створенні імунітету у птиці 3 допомогою традиційних вакцин є: інтерференція материнських антитіл з вакцинним вірусом i вплив цього чинника на розвиток імунітету а саме: відсутність серологічної диференціації між вакцинованою і інфікованою птицею (DIVA); низька кореляція між гуморальною відповіддю (гемаглютинуючі антитіла) і захистом, через низьку чутливість реакції гемаглютинації, відсутність прямої кореляції між дослідженнями в реакції гемаглютинації і наявністю клітинного імунітету, що відіграє важливу роль у захисті птиці від НХ.

При застосуванні вакцин в залежності від епізоотичного благополуччя щодо НХ необхідно встановити, до якої 34 груп належить штам HX, який циркулює в даному господарстві: велогенний, мезогенний, лентогенний, апатогенний. Клінічна та морфологічна картина, в залежності від групи, може проявлятися нейротропними, вісцеротропними, ентеротропними, респіраторними ознаками. В даний час констатують новий прояв НХ, викликаний велогенним генотипом VII. Характерним для нього є висока патогенність 
збудника, що викликає до 80-100 \% смертності, ранні терміни зараження НХ (у віці 14 днів) 3 піком смертності у віці близько трьох тижнів. У зв'язку з цим надійний специфічний імунний захист має першочергове значення. Застосування векторних вакцин, порівняно з іншими живими та інактивованими, моно- та полівалентними вакцинами, є більш привабливим, оскільки розширює можливості біологічного захисту поголів'я [ 1].

У зв'язку з цим, з'являється ідеальна можливість для використання векторної вакцини проти HX, яка безпечна і забезпечує розвиток імунітету після одноразового застосування без інтерференції з материнськими антитілами.

ВЕКТОРМУН HVT NDV - генно-інженерна вакцина, яка представляє собою вірус герпесу індичок (штам HVT FC-126), у ДНК якого вбудований ген F, який кодує протективний епітоп вірусу НX .

Переваги векторної вакцини ВЕКТОРМУН HVT NDV:

- містить F протеїн НX, який є основним імуногенним протеїном при захисті від НХ;

- відсутня інтерференція з материнськими антитілами до вірусу НХ;

- застосовується в інкубаторії;

- зменшується стрес;

- викликає тривалий надійний імунітет до 10 тижнів;

- встановлено однорідний рівень специфічних антитіл;

- видаляє польовий вірус із стада;

- знижуються витрати на додаткові вакцинації.

Векторна вакцина ВЕКТОРМУН HVT NDV викликає надійний захист проти НX i значно знижує поширення вірусу в навколишньому середовищі. Вакцина не викликає побічних реакцій і не взаємодіє 3 іншими вакцинами в респіраторному тракті курчати, наприклад 3 вакциною проти інфекційного бронхіту курей. Повторювані цикли реплікації рекомбінантного вірусу герпесу індичок (HVT) стимулюють тривалий імунітет проти НХ. Використання векторної вакцини на основі вірусу HVT в інкубаторії повністю вирішує проблему взаємодії вакцинного вірусу з материнськими антитілами, на відміну від живих та інактивованих вакцин.

Векторні вакцини використовуються для профілактики декількох захворювань (векторний вакцинний вірус + ділянка ДНК іншого вірусу). Можливе застосування комбінованих програм вакцинації, наприклад, первинна вакцинація векторної вакциною (HVT-ND - BEКTOРMУН HVT-NDV) і вакцинація живою атенуйованою вакциною (Севак Вітаброн Л) ВЕКТОРМУН HVT-NDV впливає на формування широкого повноцінного захисту з активізацією факторів гуморального та клітинного імунітету та стимулювання місцевого імунітету верхніх дихальних шляхів, ротової порожнини, кон'юнктиви, нервових волокон шлунково-кишкового тракту, дихальних шляхів і репродуктивних органів. Ці якості дозволяють ефективно використовувати ВЕКТОРМУН НVT-NDV в програмах при ліквідації вогнищ і захисту птиці від НХ $[1,2]$.

Метою нашої роботи було визначення ефективності вакцини ВЕКТОРМУН HVT-NDV при одноразовому застосуванні в інкубаторі за різних серологічних методів.

Матеріли і методи. Сироватки крові від бройлерів кросу КОББ - 500 вакцинованих векторною вакциною ВЕКТОРМУН HVT-NDV на 3, 8,10, 16, 31, 35, 43, 48 та 56 добу вирощування, тест-набір фірми ID vet, Франція для постановки IФА, антиген вірусу НХ для постановки реакції затримки гемаглютинації (РЗГА), планшети.

Результати й обговорення. Визначали у динаміці рівень протективних антитіл до вірусу НХ у сироватках крові курчат, вакцинованих одноразово вакциною ВЕКТОРМУН HVT-NDV в інкубаторі. Для порівняльної оцінки різних методів серологічних досліджень за допомогою тест-набору фірми ID vet, Франція та РЗГА з метою визначення специфічних антитіл до вірусу НХ після одноразової вакцинації у інкубаторі вакциною ВЕКТОРМУН НVT- 
NDV були відібрані сироватки крові від бройлерів на 3, 8,10, 16, 31, 35, 43, 48 та 56 добу вирощування. Результати наведені на рисунках 1, 2.

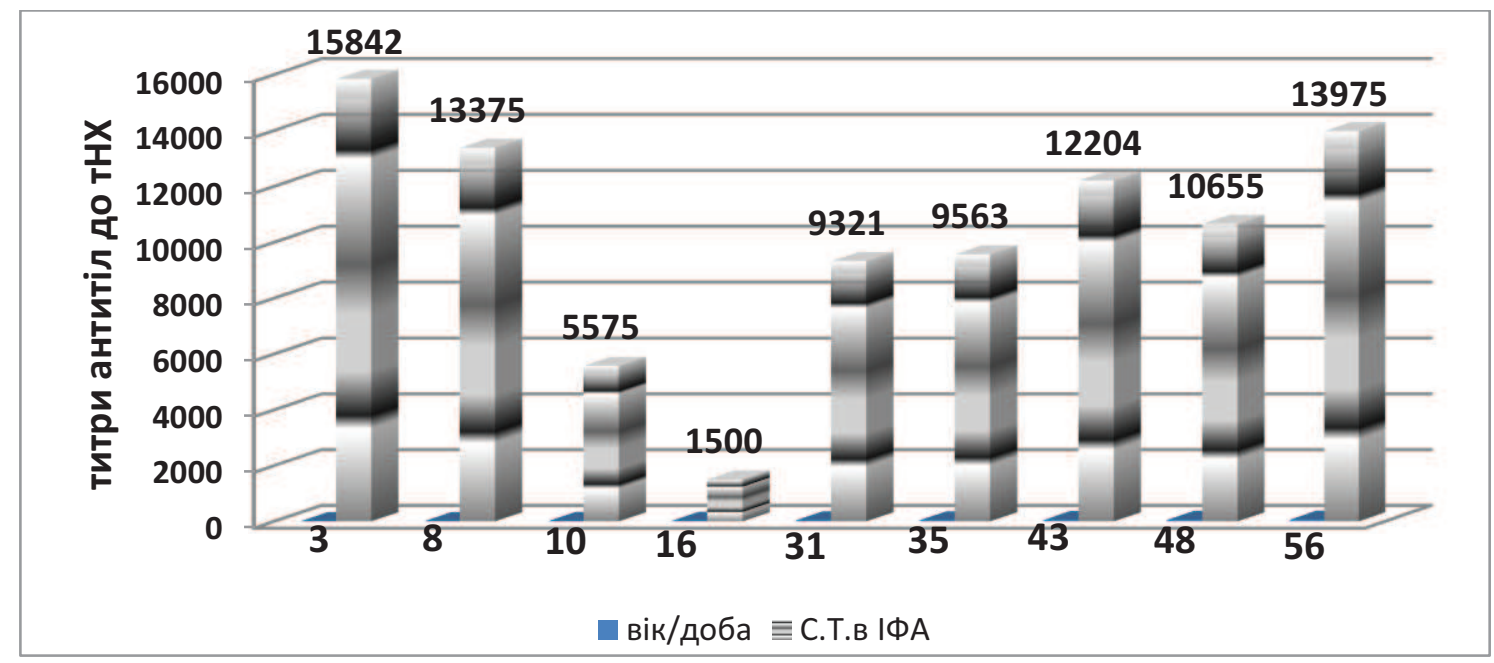

Puc.1. Динаміка середніх титрів АТ до вірусу НХ за одноразової вакцинації Вектормун HVT-NDV бройлерів в інкубаторі ( ID vet, Франція)

У результаті проведених серологічних досліджень сироваток крові від різновікових груп бройлерів в IФА (тест-набір фірми ID vet, Франція) виявлені протективні антитіла до вірусу HX рівень яких коливався у межах базової норми впродовж всього періоду вирощування, тобто 31 по 56 добу. Проте, середній титр знизився на 10 добу у 2,8 раза $\mathrm{i}$ відповідав базовій нормі, а на 16 добу становив 1500. Через 15 діб рівень середнього титру підвищився у 6,2 раза і на 31 добу становив 9321 (базова норма). На 56 добу рівень середніх титрів відповідав титрам, які були у 8-добових бройлерів. Таким чином, бройлери, що були вакциновані одноразово в інкубаторі векторною вакциною ВЕКТОРМУН HVT-NDV до 56 доби вирощування зберігали протективні антитіла до вірусу НХ.

Одночасно визначали у динаміці рівень захисних антитіл до вірусу НХ у сироватках крові бройлерів, вакцинованих одноразово вакциною ВЕКТОРМУН HVT-NDV в інкубаторі в РЗГА. Результати наведені на рис. 2.

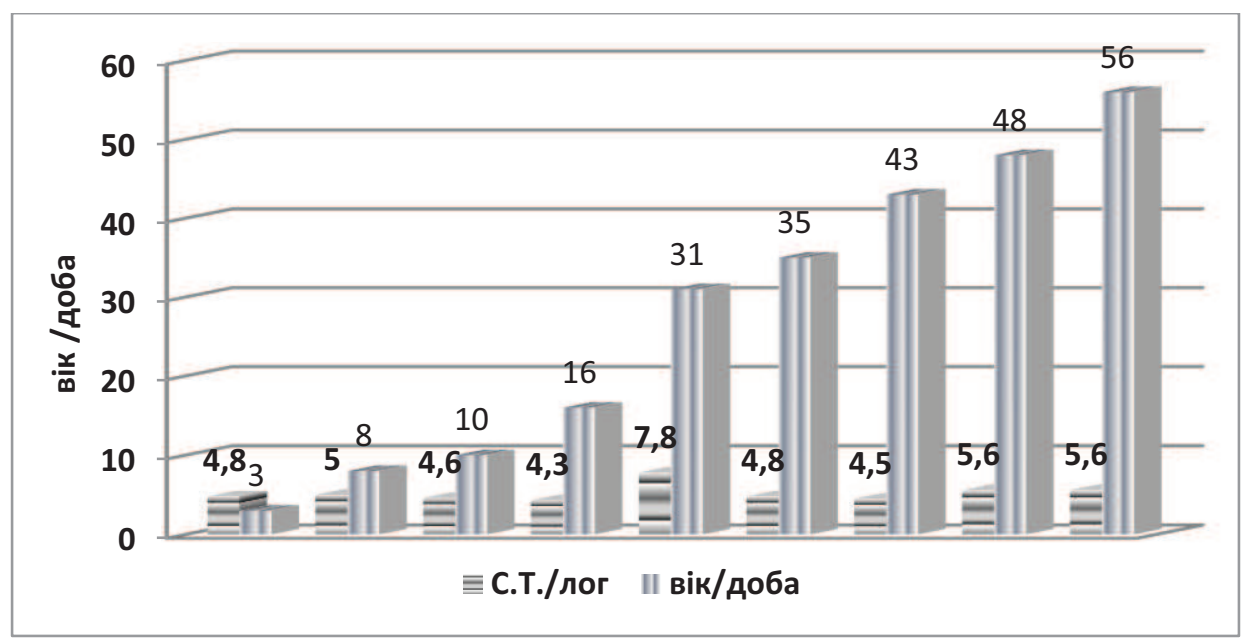

Puc. 2. Динаміка середніх титрів АТ до вірусу НХ за одноразової вакцинації Вектормун HVT-NDV бройлерів в інкубаторі (РЗГА, лог $)$ 
У результаті проведених серологічних досліджень сироваток крові від різновікових груп бройлерів у РЗГА виявлені протективні антитіла до вірусу НХ рівень яких коливався у межах базової норми від 4,3 лог2 до 7,8 лог2 впродовж всього періоду вирощування, тобто 31 по 56 добу. Проте, рівень середніх титрів знизився на 16 добу і становив 4,3 лог $і$ і відповідав базовій нормі. Середній титр підвищився в 1,6 раза на 31 добу становив 7,8 лог2 (базова норма). На 48 та 56 добу середні титри зберігалися на рівні 5,6 лог2.

Таким чином, обидва методи як ІФА (тест-набір фірми ID vet, Франція), так РЗГА чутливі і виявляють протективні антитіла до вірусу НХ у сироватках крові бройлерів, вакцинованих одноразово вакциною ВЕКТОРМУН HVT-NDV в інкубаторі. Метод IФА ID vet корелює з тестом РЗГА при дослідженні сироваток на наявність протективних антитіл до вipycy HX.

\title{
В И С Н О В К И
}

1. При порівняльній оцінці двох методів серологічного контролю ефективності вакцинації бройлерів вакциною ВЕКТОРМУН HVT-NDV проти НХ обидва методи як за допомогою IФА (тест-набору фірми ID vet, Франція), так РЗГА $є$ чутливі і виявляють протективні антитіла до вірусу НХ у сироватках крові бройлерів.

2. Одноразова вакцинація в інкубаторі векторною вакциною ВЕКТОРМУН HVT-NDV проти НX є абсолютно достатньою для формування та створення стійкого імунітету проти НX, дозволяє знизити вплив стресу, у порівнянні з масовими вакцинаціями в пташнику методом випоювання.

3. При застосуванні векторної вакцини відсутнє горизонтальне поширення вакцинного вірусу: виключається ризик зараження навколишнього середовища збудниками вірусних хвороб, яке може призвести до безконтрольного зараження птиці.

4. Застосування векторної вакцини забезпечує стабільну епізоотичну ситуацію в господарстві: не викликає поствакцинальних реакцій, поширення вакцинного вірусу («роллінг» інфекція), підвищує імунний статус стада, тим самим знижує негативний вплив вірусних та бактеріальних агентів на організм птиці протягом періоду вирощування та кількість вакцинацій птиці, викликає тривалий імунітет, тому, як правило, відсутня необхідність ревакцинації в польових умовах.

Перспективи досліджень. У подальшому плануються серологічні дослідження на ефективність векторної вакцини в залежності від епізоотичної ситуації.

\section{EFFECTIVE INNOVATIONS PREVENTION NEWCASTLE DISEASE}

\author{
I. K. Avdosieva, O. B. Basarab, V. V. Reghenchuk, I. L. Melnychuk \\ State Scientific Research Control Institute of Veterinary Medicinal Products \\ and Feed Additives \\ 11, Donetska str., Lviv, 79019, Ukraine
}

\section{S U M M A R Y}

The article presents the comparative evaluation of two methods of serologic control of the effectiveness of broiler vaccination with VECTORMUN HVT-NDV vaccine against Newcastle disease (NH). It has been established that both methods, such as ELISA (test system of the company IDvet, France), and RZGA are sensitive and detect protective antibodies to the NH virus in serum broilers. Single vaccine incubation with vector vaccine VECTORMUN HVT-NDV vs. NH is absolutely sufficient for the formation and establishment of a stable immunity against $\mathrm{NH}$, reduces the stress effect compared to mass vaccination in the poultry manure. 
With the use of a vector vaccine there is no horizontal distribution of the vaccine virus: the risk of contamination of the environment with pathogens of viral diseases is excluded, which may lead to uncontrolled infection of the bird.

The use of the vector vaccine provides a stable epizootic situation in the farm: it does not cause post-vaccination reactions, the spread of the vaccine virus ("rolling disease"), increases the immune status of the herd, thereby reducing the negative impact of viral and bacterial agents on the body of the bird during the growing season and the number of bird vaccinations, causes prolonged immunity, therefore, as a rule, there is no need for revaccination in field conditions.

The vector vaccine VECTORMUN HVT NDV provides reliable protection against NH and significantly reduces the spread of the virus in the environment. The vaccine does not cause adverse reactions and does not interact with other vaccines in the chicken respiratory tract, for example with a vaccine against infectious bronchitis of chickens. Repeated cycles of replication of the recombinant herpes-virus (HVT) stimulate long-term immunity against NH. The use of the HVT vector vaccine in the incubator completely addresses the problem of the interaction of the vaccine virus with maternal antibodies, as opposed to live and inactivated vaccines.

Keywords: NEWCASTL DISEASE, VECTOR VACCINES, HVT-NDV VECTORMUNES, HEMAGLUTNATION DELAY REACT, ELISA (ID VET, FRANCE).

\title{
ЭФФЕКТИВНЫЕ ИННОВАЦИИ ПРОФИЛАКТИКИ НЬЮКАСЛСКОЙ БОЛЕЗНИ ПТИЦ
}

\author{
И. К. Авдосьева, О. Б. Басараб, В. В. Регенчук, И. Л. Мельничук
}
Государственный научно-исследовательский контрольный институт ветеринарных препаратов и кормовых добавок, вул. Донецька, 11, г. Львов, 79019, Украина

\section{А Н Н О Т А ЦИ Я}

В статье представлены данные сравнительной оценки 2-х методов серологического контроля эффективности вакцинации бройлеров вакциной ВЕКТОРМУН HVT-NDV против ньюкаслской болезни (НБ). Установлено, что оба метода как ИФА (тест-набор фирмы ID vet, Франция), так РЗГА чувствительны и проявляют протективные антитела к вирусу НХ в сыворотках крови бройлеров. Одноразовая вакцинация в инкубаторе векторной вакциной ВЕКТОРМУН HVT-NDV против HX абсолютно достаточным для формирования и создания устойчивого иммунитета против НХ, позволяет снизить влияние стресса по сравнению с массовыми вакцинациями в птичнике методом выпойки.

При применении векторной вакцины отсутствует горизонтальное распространение вакцинного вируса: исключается риск заражения окружающей среды возбудителями вирусных болезней, которое может привести к бесконтрольному заражению птицы.

Применение векторной вакцины обеспечивает стабильную эпизоотической ситуации в хозяйстве: не вызывает поствакцинальных реакций, распространение вакцинного вируса ( «роллинг» инфекция), повышает иммунный статус стада, тем самым снижает негативное влияние вирусных и бактериальных агентов на организм птицы в период выращивания и количество вакцинаций птицы, вызывает длительный иммунитет, поэтому, как правило, отсутствует необходимость ревакцинации в полевых условиях.

Ключевые слова: НЬЮКАСЛСКАЯ БОЛЕЗНЬ, ВЕКТОРНЫЕ ВАКЦИНЫ, ВЕКТОРМУН HVT-NDV, РЕАКЦИЯ ЗАДЕРЖКИ ГЕМАГГЛЮТИНАЦИИ, ИФА (ФИРМА ID VET, ФРАНЦИЯ). 
1. Calnek B. W. Diseases of Poultry // P. 1991-1231.

2. Ефективність вакцини Вектормун проти ньюкаслської хвороби бройлерів // І. К. Авдос'єва, О. Б. Басараб, В. В. Регенчук, И. Л. Мельничук // Науково-технічний бюлетень ДНДКІ ветпрепаратів. — 2016. - Випуск 17, № 2. - С. 174-180.

\title{
References
}

1. Calnek B. W. Diseases of Poultry // P. 1991-1231.

2. Avdosjeva I. K., Basarab O. B., Regenchuk V. V., Melnychuk I. L. Efektyvnist' vaktsyny Vektormun proty njukaslskoji khvorooby brojleriv / Naukovo-tekhnichnyji bulletin DNDKI vetpreparativ. - 2016. - vypusk 17, № 2. - S. 174-180.

Рецензент - I. М. Кушнір, д. вет. н., ДНДКІ вепрепаратів та кормових добавок.

\section{ІМУНОБІОЛОГІЧНІ ВЛАСТИВОСТІ ПОЛЬОВИХ КУЛЬТУР АТИПОВИХ МІКОБАКТЕРІЙ}

\author{
I. А. Бібен, канд. вет. наук, доиент, \\ А. О. Сосницька, студентка магістратури ФВМ, \\ Є. В. Удовииький, аспірант ФВМ, \\ В. В. Зажарський, канд. вет. наук, доиент
}

Дніпровський державний аграрно-економічний університет,

вул. С. Єфремова 25, м. Дніпро, 49000, Україна

При проведенні симультанного внутрішньошкірного алергічного дослідження 12 голів ВРХ встановили, щь вони сенсибілізовані алергенами з атипових мікобактерій. Тварини були клінічно здорові і знаходилися в місчевості, яка є благополучною щзодо інфектопатологіi. При бактеріологічному дослідженні коров'ячого гною з передпосівною обробкою біоматеріалу за методом А. П. Алікаєвої вдалося ізолювати культури мікобактерій, які за комплексом характеристик були ідентифіковані як Mycobacterium phlei; M. flavenscen; M. vaccae; M. terra. При дослідженні сенсибілізуючих і патогенних властивостей на мурчаках з'ясували, щуо всі ізоляти мають виражений сенсибілізуючий потенщіал $і$ не викликають патологічних змін 8 організмі інфікованих тварин. Найбільша інтенсивність алергічних реакцій спостерігалася через 60 діб після інфікування, потім йде спад $i$ звільнення організму від атипових мікобактерій. Ізоляти в організмі білих мишей підвищували неспецифічну резистентність, що було показано при зараженні DCL P. multocida sb. gallicida білих мишей, превентивно інфікованих атиповими мікобактеріями. Найбільшими протективними $і$ пробіотичними потенціями володіла культура М. vассае.

Ключові слова: АТИПОВІ МІКОБАКТЕРІЇ, M. VACCAE, ІМУНОСТИМУЛЯЦІЯ, ПРОБІОТИЧНІ КУЛЬТУРИ, БІОПРОБА, Р. MULTOCIDA SB. GALLICIDA, БIOMATЕРIАЛ. 